\title{
The ichthyofauna of the Rio Carinhanha basin, one of the main tributaries of the Rio São Francisco
}

\author{
Gilberto Nepomuceno Salvador ${ }^{1,2}$; Ruanny Casarim ${ }^{3,5}$; Gustavo Ribeiro Rosa ${ }^{4}$; Yuri Malta Caldeiraa ${ }^{3,6}$ \& Paulo Santos Pompeu ${ }^{3,7}$ \\ 1 Universidade Federal do Pará (UFPA), Instituto de Ciências Biológicas (ICB), Laboratório de Ecologia e Conservação (LABECO). \\ Belém, PA, Brasil. ORCID: http://orcid.org/0000-0002-3598-6469. E-mail: curimata_gilbert@hotmail.com \\ 2 Pontifícia Universidade Católica de Minas Gerais (PUC-MINAS), Museu de Ciências Naturais (MCN). Belo Horizonte, MG, Brasil. \\ ${ }^{3}$ Universidade Federal de Lavras (UFLA), Departamento de Biologia, Setor de Ecologia e Conservação, Programa de Pós-Graduação em Ecologia \\ Aplicada (PPGECO). Lavras, MG, Brasil. \\ ${ }^{4}$ Pontifícia Universidade Católica de Minas Gerais (PUC-MINAS), Programa de Pós Graduação em Biologia de Vertebrados. \\ Belo Horizonte, MG, Brasil. ORCID: http://orcid.org/0000-0002-1790-1089. E-mail: gustavoribeirorosa@hotmail.com \\ ${ }^{5}$ ORCID: http://orcid.org/0000-0003-2969-1311. E-mail: rucasarim@gmail.com \\ ${ }^{6}$ ORCID: http://orcid.org/0000-0003-4297-7090. E-mail: yurimc86@gmail.com \\ ${ }^{7}$ ORCID: http://orcid.org/0000-0002-7938-1517. E-mail: pompeups@gmail.com
}

\begin{abstract}
The ichthyofauna of the Rio São Francisco basin is relatively well-documented. However, most of this knowledge is concentrated at the upper stretch of its catchment area. In this study, we compile a list of species encompassing almost the entire length of the Rio Carinhanha, an important tributary from upper-middle section of the Rio São Francisco, including a comprehensive diversity of environments. A total of 99 species from 8 orders and 27 families were recorded. Five species are considered non-native, six classifieds as long distance migrants, and three as vulnerable. The orders with the greatest richness of native species were Characiformes and Siluriformes. Characidae was the most represented family, followed by Loricariidae. The main river channels were the richest environments sampled, followed by floodplain lagoons, veredas, and streams. The Carinhanha basin has important lotic remnants, thus it has several migratory fish populations as well as endangered species. This study demonstrates the importance of cataloguing the still poorly explored tributaries of the upper-middle section of the Rio São Francisco basin.
\end{abstract}

Key-Words. Cerrado; Freshwater; Checklist; Rio Itaguari; Rio Cochá; Grande Sertão Veredas National Park.

\section{INTRODUCTION}

The ichthyofauna of the Rio São Francisco has been studied since the eighteenth century, when Prochilodus marggravii was first described by the naturalist Johann Julius Walbaum (Britski et al., 1988). After more than a century, the basin has one of the most well-known ichthyofauna in the Neotropical region with 241 recorded native species, $70 \%$ of them with confirmed occurrences in the state of Minas Gerais (Alves \& Pompeu, 2010; Alves et al., 2011; Barbosa et al., 2017). Despite the significant knowledge about the fish assemblages within the catchment, the distribution of studied areas is uneven, with the greatest concentrations of research occurring around the most populous regions (Alves et al., 2011). Surveys of species in highland rivers (Casatti \& Castro, 1998, Vieira et al., 2005; Alves \& Leal, 2010; Alves \& Pompeu, 2010; Domingos et al., 2013), some reservoirs (Silva et al., 2006; Prado \& Pompeu, 2014; Sanches et al., 2014), and some floodplain lagoons of the upper and upper-middle sections of the Rio São Francisco (Sato et al., 1987; Pompeu \& Godinho, 2003; Luz et al., 2012) are available. However, the fish assemblages of some of the main tributaries of the upper-middle section of the Rio São Francisco remains poorly known (Alves et al., 2009), as is the case of the Rio Carinhanha basin.

The great regional importance of the Rio Carinhanha contrasts with the scarcity of knowledge concerning the basin's ichthyofauna. The Carinhanha constitutes one of the most preserved tributaries of the Rio São Francisco basin, running through well-preserved areas including some important protected zones such as Grande Sertão Veredas National Park (Borges \& Santos, 2009). The river also is one of the largest perennial rivers in the central section of the São Francisco basin, a region of notorious water stress (Pereira et al., 2007; Mendes et al., 2015). Despite its importance, there has only been one systematic survey of the ichthyofauna in the basin (IBGE, 2007). However, that survey did not consider all its richness due to the 
restricted area sampled, nor did it evaluate the distribution of the species in the catchment's different habitats.

The Carinhanha is considered a priority area for fish fauna conservation in the central area of the Rio São Francisco basin (Drummond et al., 2005; Rosa et al., 2003) because it represents an important lotic remnant of the basin. However, all of the basic requirements for adequate conservation strategies are lacking, especially because the species composition remains unknown. Therefore, in this study we compile a list of species, encompassing the full extent of the catchment and record the diversity of the basin's habitats.

\section{MATERIAL AND METHODS}

\section{Study area}

The Rio São Francisco basin is one of the largest river basins in Brazil, covering five Brazilian states (Alagoas, Bahia, Minas Gerais, Pernambuco, and Sergipe), and is divided into four sections: upper, upper-middle, lower-middle, and lower (Drummond et al., 2005; Paiva, 1982; Sato \& Godinho, 2003). The main tributaries of the Rio São Francisco flow into the upper-middle section (Godinho \& Godinho, 2003) and include the Rio Carinhanha, which divides states of Minas Gerais and Bahia (Fig. 1).
The Rio Carinhanha is $468 \mathrm{~km}$ long. Its basin exhibits an elongated shape (Viglio et al., 2011), running in an easterly direction, and covering an area of 1.7 million hectares (Borges \& Santos, 2009). Although it occupies $2.7 \%$ of the total area of the Rio São Francisco basin, the Rio Carinhanha drainage contributes $6.5 \%$ of the average flow of the main river (Pereira et al., 2007). This can be explained by the types of soils in the region: urucuia sandstone and deposits containing lateritic detritus, superimposed by Quartzarenic Neosols (Borges, 2009), have relatively high rates of rainwater infiltration compared to other types of soils (Gaspar et al., 2007).

There are many protected areas in the Carinhanha basin (MMA/IBAMA, 2003). Six of them are part of a set of protected areas called Mosaico Sertão Veredas-Peruaçu (Moraes, 2011), which cover approximately 30\% of the Carinhanha drainage basin. The Grande Sertão Veredas National Park is one of the largest protected area in the region and is part of this integral protection group. The other protected areas, Porto Cajueiro, Cochá-Gibão, Veredas do Caraíba, Gibão-Flexeiras, and Triângulo I, are classified into sustainable use (Dudley, 2008).

The predominant biomes along the course of the Rio Carinhanha are the Brazilian savanna (cerrado) and the tropical dry forest (caatinga). Its leads to great variability to the mean of the annual rainfall along the basin, being closer that observed in cerrado on its headwaters (near to

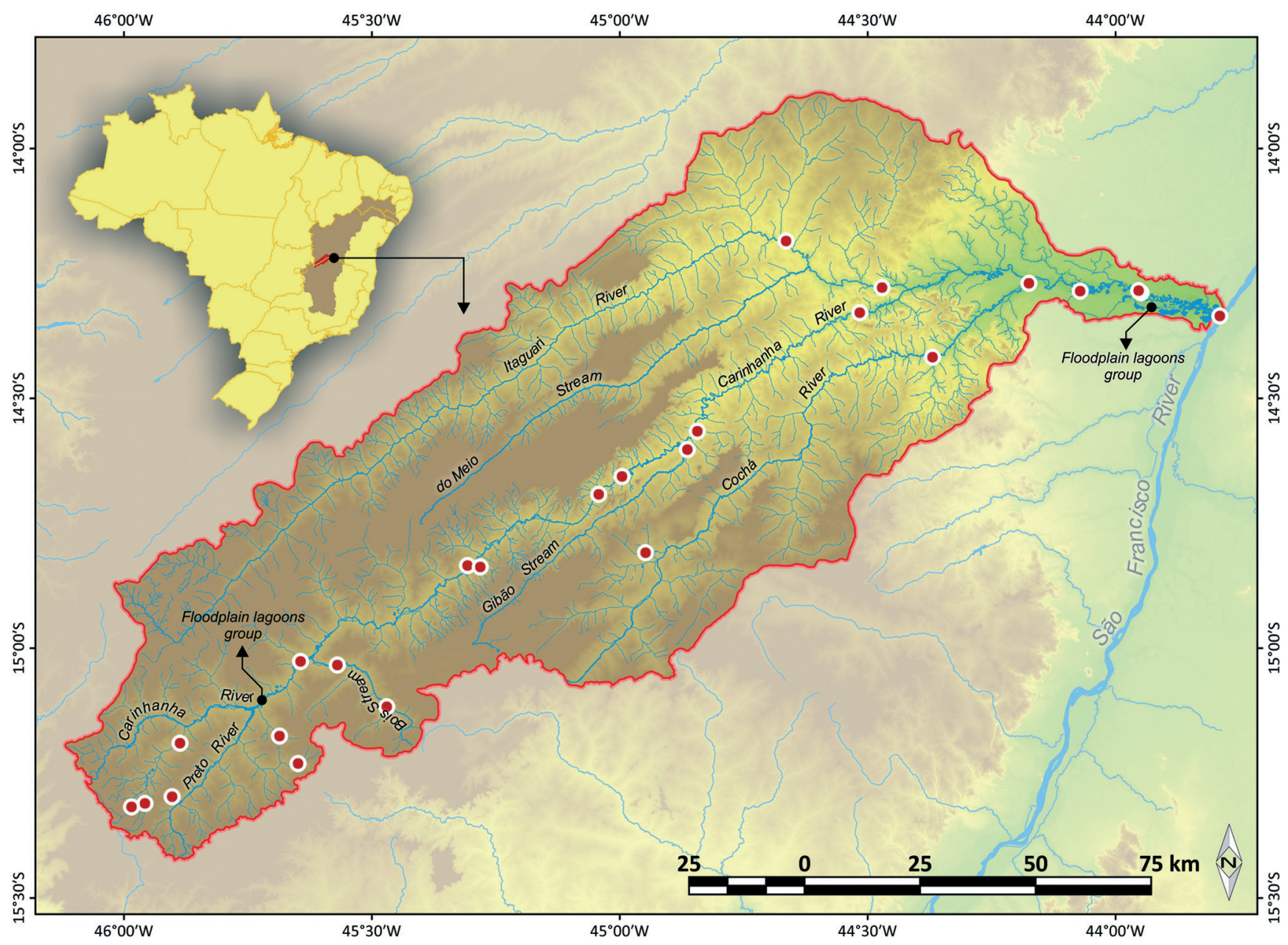

Figure 1. Distribution of the sampled sites across the Rio Carinhanha basin. 
$1,500 \mathrm{~mm}$ ), and closer to the caatinga on its mouth (near to $700 \mathrm{~mm}$ /year) (Borges, 2009; EMBRAPA, 2012; Silva et al., 2018). Veredas (Brazilian palm swamp) and floodplain lagoons are both abundant along the Carinhanha basin. The first formation occurs mainly along the upper portion of the basin. There are numerous floodplain lagoons near the mouth of the Rio Preto (more than 130 floodplain lagoons with an average size of $0.2 \mathrm{ha}$ ), and in the lower river (120 floodplain lagoons with an average size of $8.2 \mathrm{ha}$ ). Furthermore, there are also permanent ponds, a lentic environment isolated from the river channel.

\section{Fish Sampling and Identification}

Sampling was undertaken at 25 sites in the Rio Carinhanha basin (Fig. 1) from September 2014 to April 2015. The sampled water bodies included 3 streams, 6 veredas, 2 floodplain lagoons, 2 permanent ponds, and 12 points along the main channels of the Rio Carinhanha as well as 2 of its tributaries: the Rio Itaguari and Rio Cochá (Figs. 2 and 3; Supplementary Materials 1). We considered veredas (palm swamps) to be all streams classified as Strahler third order which flowed into hydromorphic ground and had a poorly defined channel surrounded by buritis (Mauritia flexuosa) palm trees (Silva \& Bates, 2002). We differentiated floodplain lagoons from permanent ponds by its position in the drainage basin. While floodplain lagoons are located near the Rio Carinhanha channel and are directly influenced by its flood pulses, permanent ponds are lentic environment away from the floodplains and lacking flood pulse influence (Costa, 2002; Tavares-Júnior et al., 2020).

The main river channel of the Carinhanha (Figs. 2A and $2 \mathrm{~B}$ ) and Itaguari (Fig. 2C) as well as one floodplain lagoon (Fig. 3C) were sampled using gillnets with mesh sizes ranging from 3 to $16 \mathrm{~cm}$ (between opposing knots) at each sampling site. The gillnets were set up in the af-
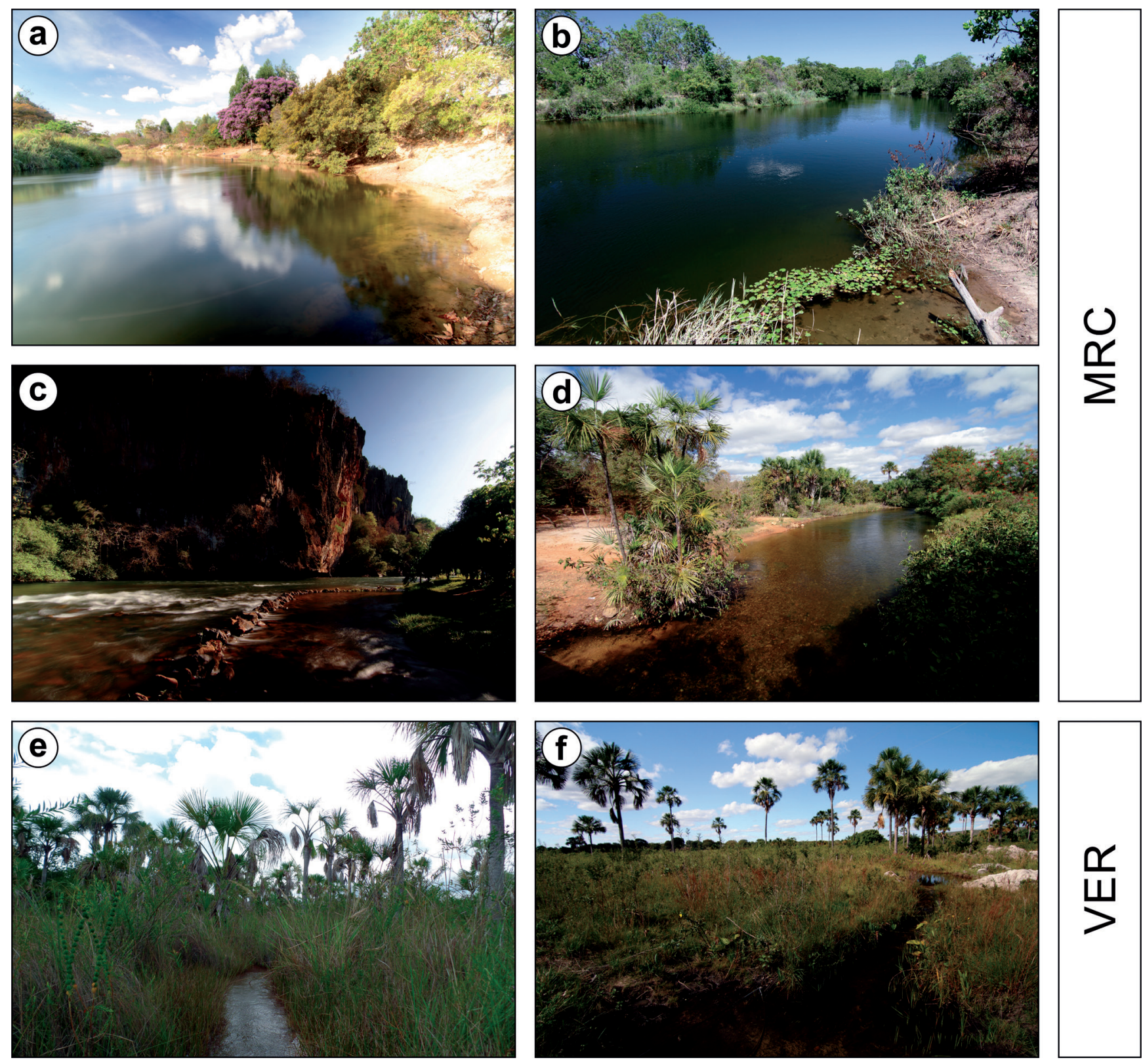

Figure 2. Aquatic habitats [main river channels (MRC) and veredas (VER)] at the Rio Carinhanha basin. 
ternoon and removed the following morning, staying approximately 15 hours submerged. At each of these three locations, two seinings and an additional 15 sieve samplings were carried out as supplementary methodology. The seine was $3 \mathrm{~m}$ long by $1.5 \mathrm{~m}$ high, and the sieve had a diameter of approximately $0.2 \mathrm{~m}^{2}$; both with mesh size $0.5 \mathrm{~mm}$. In the main channel of the Rio Cochá (Fig. 2D) and in another floodplain lagoon (Fig. 3D), only sieve samplings were done due to environmental conditions; at the permanent ponds (Figs. 3E and 3F), only seining was undertaken.

To sample fish communities in streams and veredas (Figs. 3A, 3B, 3E and 3F), a $150 \mathrm{~m}$ long section was delimited in each study site. Fish collections were undertaken against the water-flow (i.e., from downstream to upstream) with hand nets $(80 \mathrm{~cm}$ in diameter, $1 \mathrm{~mm}$ stretched mesh size). Two hand nets were used for sampling, and collection time was standardized (12 minutes per cross-section, 120 minutes for each stream). Hand nets were used because of their efficiency in lower-order streams. The sampling effort was the same in all streams.

After capture, the fish were euthanized with lethal doses of anesthetic and then fixed in $10 \%$ formalin solution. In the laboratory, we transferred the fishes to $70 \%$ ethanol and identified them to the species level through dichotomous keys from Britski et al. (1988) and recent literature on the ichthyofauna of the São Francisco basin. The scientific names followed Fricke et al. (2020). Voucher specimens were deposited in the ichthyological collections of the Museum of Natural Sciences of PUC-Minas (MCNIP) and the Laboratory of Fish Ecology of the Federal University of Lavras (UFLA) (Supplementary Materials 2).

\section{Data analysis}

All analyses were undertaken using qualitative data from this field sampling. The species were classified ac-
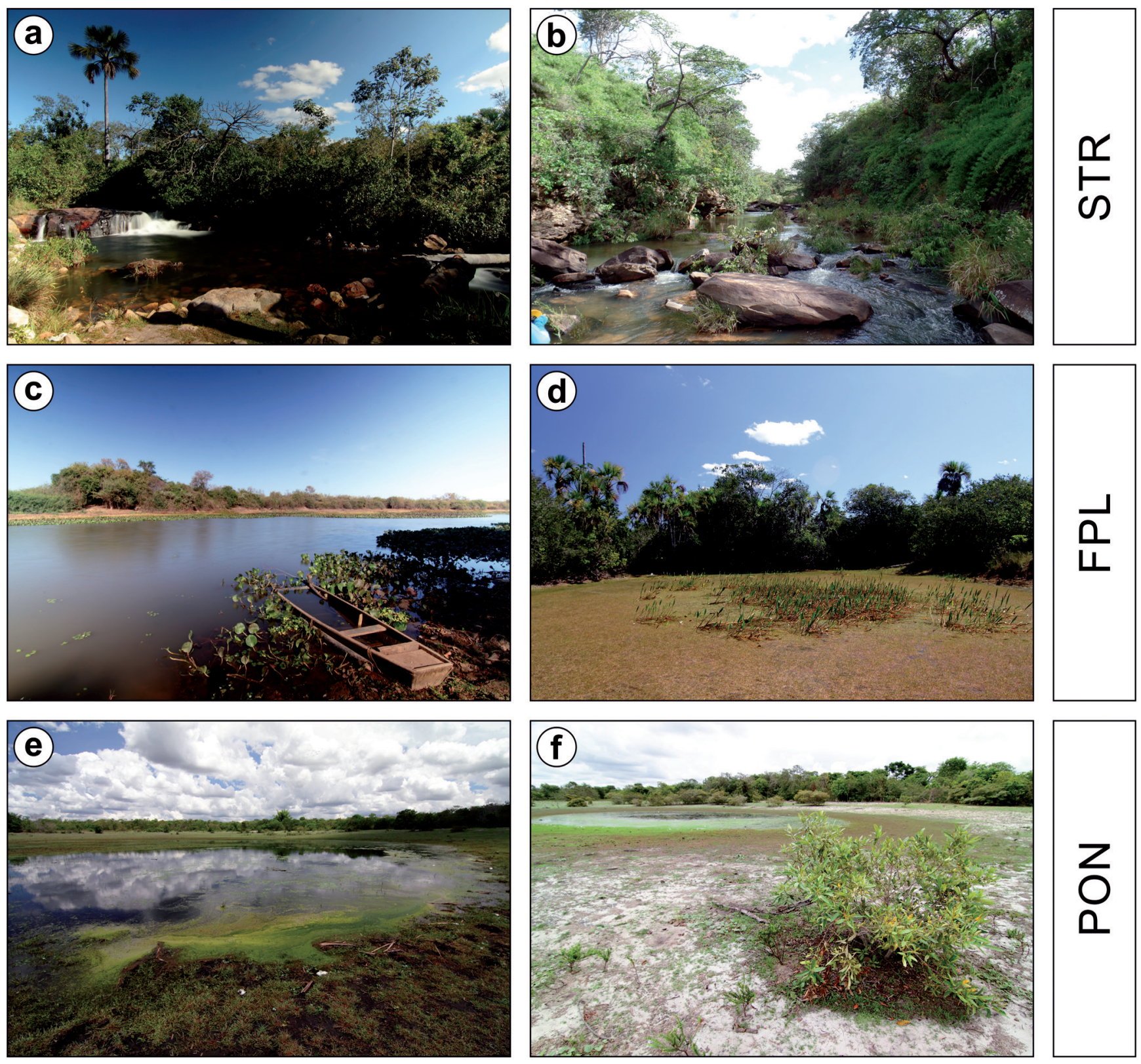

Figure 3. Aquatic habitats [streams (STR), floodplain lagoons (FPL), and permanent ponds (PON)] at the Rio Carinhanha basin. 
cording to their original distribution (native or non-native; Alves \& Leal, 2010), their reproductive characteristics, sedentary or migratory (Sato \& Godinho, 2003), and their conservation status (Vieira et al., 2008; MMA, 2014; IUCN, 2015).

Individuals were classified into orders and families following Van der Laan \& Fricke (2020). The relative richness of native species in each order and family was considered. The distribution of species in the following five different habitats within the basin were also evaluated: the main river channel (MRC) of Carinhanha and its tributaries, Itaguari and Cochá, streams (STR), veredas (VER), floodplain lagoons (FPL), and permanent ponds (PON). As a complement to our list, we incorporated species that were not recorded in our study, by checking the basin's voucher species. Subsequently, a Jaccard matrix was calculated and served as the basis for a principal coordinate analysis (PCoA) to evaluate the similarity of ichthyofauna among the five different habitats.

In order to test whether sampling was adequate, a species accumulation curve was generated through the rarefaction of the data obtained by sampling site and to estimate total basin richness, the mean of Jackknife values were used, both using Vegan package in $\mathrm{R}$ (Oksanen et al., 2013; R Core Team, 2015).

\section{RESULTS}

A total of 99 species distributed across 8 orders and 27 families were recorded for the Rio Carinhanha basin (Table 1; Fig. 4). Characiformes was the order with the highest richness of native species $(56 \%)$, followed by the Siluriformes (33\%), and then both Cichliformes and Gymnotiformes (3\% each) (Fig. 5). This pattern was similar in four of the five sampled habitats, with minor variations principally between the first two orders. The exception occurred in PON, in which the only two species recorded were Characiformes. Characidae was the most representative family with $23 \%$ of recorded species, followed by Loricariidae (11\%), and Anostomidae (7\%) (Fig. 6). Of all the families recorded in the Carinhanha basin, 70\% had a richness of less than three species. The habitat MRC was the richest environment among the sampled species with $82 \%$ of the species recorded for the entire basin, followed by FPL (41\%), VER (33\%), and STR (20\%). Of the two species recorded in PON, one is probably new to science (Characidium sp.). No single species was recorded in all habitats, but $16 \%$ were recorded in three or four sites, and $84 \%$ of the species showed a restricted distribution to just one or two habitat types (Table 1).

Five of the sampled species are considered introduced in the basin, one characiform (Metynnis lippincottianus), one siluriform (Hoplosternum littorale), and three cichliforms (Astronotus ocellatus, Cichla piquiti, and Coptodon rendalli). The distribution of the introduced species was restricted to the MRC and FPL in the lower section of the Rio Carinhanha. Six species (Brycon orthotaenia, Megaleporinus obtusidens, Prochilodus argenteus, Prochilodus costatus, Salminus franciscanus, and
Pseudoplatystoma corruscans) are classified as long-distance migrators and occurred in MRC and FPL. Brycon orthotaenia, S. franciscanus, and P. corruscans were recorded only in the FPL close to the confluence of the two rivers, while the other migratory species were only recorded in the MRC of Carinhanha and Itaguari. Three species are classified as vulnerable: Brycon orthotaenia (Characiformes) (IUCN, 2015), Bagropsis reinhardti (MMA, 2014), and Lophiosilurus alexandri (MMA, 2014). Bagropsis reinhardti was recorded only in the upper section of the two MRC (Rio Carinhanha and Rio Itaguari), while B. orthotaenia and L. alexandri occurred in both MRC and FPL habitats and were restricted to the lower section of the Rio Carinhanha.

MRC and FPL sampling sites formed a group based on their similarities, which was distinct from the group represented by VER, STR, and PON. Among the sites belonging the different habitats, those of VER showed the highest variation (Fig. 7). The species accumulation curve stabilized (Fig. 8), and the observed richness (99 species) represented $97 \%$ of the richness estimated by Jackknife 1 (102 \pm 2 species).

\section{DISCUSSION}

The Rio Carinhanha basin can be considered one of the richest tributaries of the Rio São Francisco basin, with around $40 \%$ of the known fish species for the entire São Francisco (Alves \& Pompeu, 2010; Barbosa et al., 2017). With 99 species, including Hysteronotus megalostomus, which was recorded only in the literature (Menezes et al., 2016), the Rio Carinhanha basin has the second-highest richness, second only to the Rio das Velhas basin (Alves \& Leal, 2010). However, important tributaries, such as the Paracatu, Urucuia, and Corrente rivers still lack detailed fish surveys, although some localized studies have been carried out (e.g., Belei et al., 2016). With the increase of knowledge about the fish fauna of those tributaries, we believe that some may have a similar fish richness to the Carinhanha.

The predominance of otophysians Characiformes and Siluriformes species, a pattern observed in the present study, are known to be the rule in the Neotropics (LoweMcConnell, 1987; Reis et al., 2016) and have already been observed in different studies in the Rio São Francisco basin (e.g., Britski et al., 1988; Alves \& Leal, 2010). Similarly to what was found in the present study, this pattern can also be found both in small tributaries (e.g., Casatti \& Castro, 1998), and large rivers (e.g., Alves \& Leal, 2010; Belei et al., 2016).

The record of a larger number of species at the main river channel is in accordance with the River Continuum Concept, which predicts an increase in species richness from the headwaters towards the mouth (Vannote et al., 1980) due to the increase in habitat diversity and availability (Karr \& Schlosser, 1978). The lowest richness was recorded in PON, with only two species. It can be explained by the instability of those water bodies, which almost dry out completely during the dry season (Costa, 
Table 1. Species recorded in the Rio Carinhanha basin, one of the main tributaries of the Rio São Francisco. The species identified with $\left({ }^{*}\right)$ are classified as endangered. Species followed by $(\theta)$ are classified as non-native and $(+)$ are classified as long-distance migratory species. Habitats: main river channel (MRC), streams (STR), veredas (VER), floodplain lagoons (FPL), and permanent ponds (PON).

\begin{tabular}{|c|c|c|c|c|c|}
\hline Taxon & MR & & $\begin{array}{l}|A B| \\
R \text { VE }\end{array}$ & $\begin{array}{l}\text { ITAT } \\
\text { ER FPL }\end{array}$ & PON \\
\hline ORDER CLUPEIFORMES & & & & & \\
\hline Family Engraulidae & & & & & \\
\hline Anchoviella vaillanti (Steindachner 1908) & $x$ & & & $x$ & \\
\hline ORDER CHARACIFORMES & & & & & \\
\hline Family Crenuchidae & & & & & \\
\hline Characidium cf. fasciatum Reinhardt 1867 & & & $x$ & $x$ & \\
\hline Characidium zebra Eigenmann 1909 & $x$ & $x$ & $x$ & $x$ & \\
\hline Characidium sp. & & & & & $x$ \\
\hline Family Erythrinidae & & & & & \\
\hline Hoplerythrinus unitaeniatus (Spix \& Agassiz 1829) & & & $x$ & $x$ & \\
\hline Hoplias intermedius (Günther 1864) & $x$ & & $x$ & $x$ & \\
\hline Hoplias malabaricus (Bloch 1794) & $x$ & & & & \\
\hline Family Parodontidae & & & & & \\
\hline Apareiodon hasemani Eigenmann 1916 & $x$ & & & $x$ & \\
\hline Apareiodon sp.A (following Britski et al., 1988) & $x$ & & & & \\
\hline Family Serrasalmidae & & & & & \\
\hline Metynnis lippincottianus (Cope 1870) & $x$ & & & & \\
\hline Myleus micans (Lütken 1875) & $x$ & & & & \\
\hline Pygocentrus piraya (Cuvier 1819) & $x$ & & & & \\
\hline Serrasalmus brandtii Lütken 1875 & $x$ & & & $x$ & \\
\hline Family Anostomidae & & & & & \\
\hline Leporellus vittatus (Valenciennes 1850) & $x$ & & & & \\
\hline Leporinus marcgravii Lütken 1875 & $x$ & & & & \\
\hline Leporinus piau Fowler 1941 & $x$ & & & $x$ & \\
\hline Leporinus taeniatus Lütken 1875 & $x$ & & & & \\
\hline Megaleporinus obtusidens (Valenciennes 1837) + & $x$ & & & & \\
\hline Megaleporinus reinhardti Lütken 1875 & $x$ & & & $x$ & \\
\hline Schizodon knerii (Steindachner 1875) & $x$ & & & $x$ & \\
\hline Family Curimatidae & & & & & \\
\hline Curimatella lepidura (Eigenmann \& Eigenmann 1889) & $x$ & & & $x$ & \\
\hline Steindachnerina elegans (Steindachner 1875) & $x$ & & & $x$ & \\
\hline Family Prochilodontidae & & & & & \\
\hline Prochilodus argenteus Spix \& Agassiz $1829+$ & $x$ & & & $x$ & \\
\hline Prochilodus costatus Valenciennes $1850+$ & $x$ & & & $x$ & \\
\hline Family Triportheidae & & & & & \\
\hline Triportheus guentheri (Garman 1890) & $x$ & & & $x$ & \\
\hline Family Bryconidae & & & & & \\
\hline Brycon orthotaenia Günther $1864++^{*}$ & $x$ & & & $x$ & \\
\hline Salminus franciscanus Lima \& Britski $2007+$ & $x$ & & & $x$ & \\
\hline Salminus hilarii Valenciennes 1850 & $x$ & & & & \\
\hline Family Iguanodectidae & & & & & \\
\hline Bryconops sp. & $x$ & $x$ & $x$ & $x$ & \\
\hline Family Acestrorhynchidae & & & & & \\
\hline Acestrorhynchus britskii Menezes 1969 & $x$ & & & $x$ & \\
\hline Acestrorhynchus lacustris (Lütken 1875) & $x$ & & & $x$ & \\
\hline Family Characidae & & & & & \\
\hline Astyanax bockmanni Vari \& Castro 2007 & $x$ & $x$ & $x$ & $x$ & \\
\hline Astyanax fasciatus (Cuvier 1819) & $x$ & $x$ & $\mathrm{X}$ & $x$ & \\
\hline Astyanax lacustris (Lütken 1875) & $x$ & $x$ & $x$ & $x$ & \\
\hline Astyanax rivularis (Lütken 1875) & & $x$ & $x$ & & \\
\hline Compsura heterura Eigenmann 1915 & & & $x$ & & \\
\hline Hasemania nana (Lütken 1875) & $x$ & & & & $x$ \\
\hline Hemigrammus cf. gracilis (Lütken 1875) & $x$ & & & & \\
\hline Hemigrammus marginatus Ellis 1911 & $x$ & $x$ & $x$ & $x$ & \\
\hline Hyphessobrycon micropterus (Eigenmann 1915) & $x$ & & & $x$ & \\
\hline Hyphessobrycon santae (Eigenmann 1907) & & & $x$ & & \\
\hline Hysteronotus megalostomus Eigenmann 1911 & $x$ & & & & \\
\hline Knodus moenkhausii (Eigenmann \& Kennedy 1903) & $x$ & & & & \\
\hline Lepidocharax burnsi Ferreira, Menezes \& Quagio-Grassiotto 2011 & $x$ & $x$ & & & \\
\hline Moenkhausia costae (Steindachner 1907) & $x$ & & & $x$ & \\
\hline Moenkhausia sanctaefilomenae (Steindachner 1907) & & & $x$ & & \\
\hline Orthospinus franciscensis (Eigenmann 1914) & $x$ & & & $x$ & \\
\hline Phenacogaster franciscoensis Eigenmann 1911 & $x$ & $x$ & $x$ & $x$ & \\
\hline Piabarchus stramineus (Eigenmann 1908) & $x$ & & & $x$ & \\
\hline Piabina argentea Reinhardt 1867 & $x$ & $x$ & $x$ & & \\
\hline Roeboides xenodon (Reinhardt 1851) & $x$ & & & & \\
\hline Serrapinnus heterodon (Eigenmann 1915) & $x$ & $x$ & $x$ & & \\
\hline Serrapinnus piaba (Lütken 1875) & $x$ & $x$ & $x$ & $X$ & \\
\hline
\end{tabular}

\begin{tabular}{|c|c|c|c|}
\hline Taxon & \multicolumn{3}{|c|}{$\begin{array}{c}\text { HABITAT } \\
\text { MRC STR VER FPI PON }\end{array}$} \\
\hline Tetragonopterus chalceus Spix \& Agassiz 1829 & $x$ & & $X$ \\
\hline ORDER SILURIFORMES & & & \\
\hline Family Auchenipteridae & & & \\
\hline Centromochlus bockmanni (Sarmento-Soares \& Buckup 2005) & & & $x$ \\
\hline Trachelyopterus galeatus (Linnaeus 1766) & $x$ & & $X$ \\
\hline Family Doradidae & & & \\
\hline Franciscodoras marmoratus (Lütken 1874) & & & $x$ \\
\hline Family Heptapteridae & & & \\
\hline Cetopsorhamdia iheringi Schubart \& Gomes 1959 & & & $x$ \\
\hline Imparfinis minutus (Lütken 1874) & $x$ & & $x$ \\
\hline Phenacorhamdia tenebrosa (Schubart 1964) & & & $x$ \\
\hline Pimelodella laurenti Fowler 1941 & $x$ & & \\
\hline Rhamdia quelen (Quoy \& Gaimard 1824) & $x$ & $X$ & $x$ \\
\hline Pimelodella lateristriga (Lichtenstein 1823) & & & $x$ \\
\hline
\end{tabular}

Family Pimelodidae

Bagropsis reinhardti Lütken 1874*

Pimelodus fur (Lütken 1874)

Pimelodus maculatus Lacepède 1803

Pimelodus pohli Ribeiro \& Lucena 2006

Pseudoplatystoma corruscans (Spix \& Agassiz 1829) +

Family Pseudopimelodidae

Cephalosilurus fowleri Haseman 1911

Lophiosilurus alexandri Steindachner $1876^{*}$

Family Trichomycteridae

Stegophilus insidiosus Reinhardt 1859

Family Callichthyidae

Corydoras garbei lhering 1911

Corydoras lymnades

Tencatt, Vera-Alcaraz, Britto \& Pavanelli 2013 X

Corydoras multimaculatus Steindachner $1907 \quad X$

Hoplosternum littorale (Hancock 1828) $\theta$

Family Loricariidae

Harttia longipinna Langeani, Oyakawa \& Montoya-Burgos 2001

Hisonotus vespuccii Roxo, Silva \& Oliveira 2015

Hisonotus sp.

Hypostomus margaritifer (Regan, 1908)

Hypostomus cf. lima (Lütken 1874)

Hypostomus francisci

Hypostomus velhochico Zawadzki, Oyakawa \& Britski 2017

Otocinclus xakriaba Schaefer 1997

Pterygoplichthys etentaculatus (Spix \& Agassiz 1829)

Rineloricaria sp. (similar to $R$. lima)

Megalancistrus barrae (Steindachner 1910)

\section{ORDER GYMNOTIFORMES}

Family Gymnotidae

Gymnotus gr. carapo Linnaeus 1758

Family Sternopygidae

Eigenmannia besouro Peixoto \& Wosiacki 2016

Sternopygus macrurus (Bloch \& Schneider 1801)

$\begin{array}{ll}x & x \\ x & x \\ x & x\end{array}$

\section{ORDER CYPRINODONTIFORMES}

Family Poeciliidae

Pamphorichthys hollandi (Henn 1916)

ORDER SYNBRANCHIFORMES

Family Synbranchidae

Synbranchus sp.

ORDER PERCIFORMES

Family Sciaenidae

Pachyurus francisci (Cuvier 1830)

Pachyurus squamipennis Agassiz 1831

ORDER CICHLIFORMES

Family Cichlidae

Astronotus ocellatus (Agassiz 1831) $\theta$

Cichla piquiti Kullander \& Ferreira $2006 \theta$

Cichlasoma sanctifranciscense Kullander 1983

Coptodon rendalli (Boulenger 1897) $\theta$

Crenicichla lepidota Heckel 1840

Geophagus brasiliensis (Quoy \& Gaimard 1824)
X

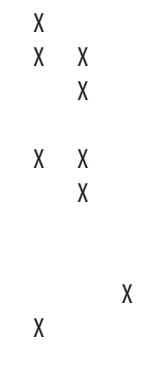

X X

$\begin{array}{lll}x & x \quad x \\ x & x\end{array}$

$x \quad x$

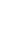

$x$

$X \quad X \quad X \quad X$

$X$

X

$x$

X

X

Serrapinnus piaba (Lütken 1875) 


\section{Characiformes}

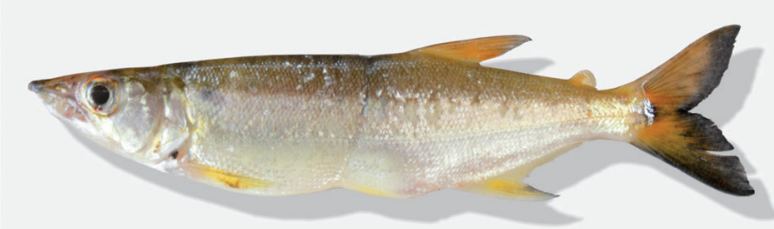

Acestrorhynchus lacustris $(M L=27 \mathrm{~cm})$

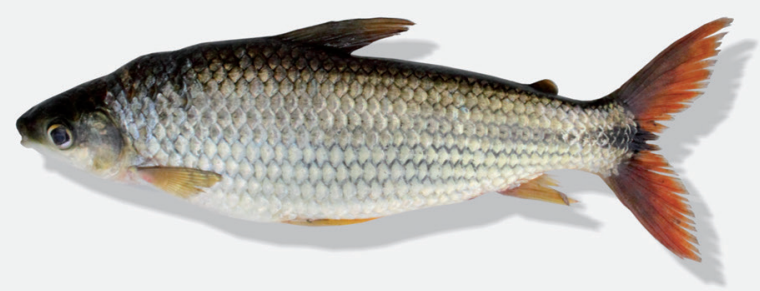

Schizodon knerii $(M L=23 \mathrm{~cm})$

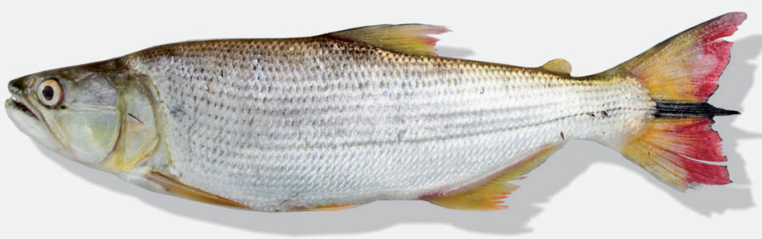

Salminus franciscanus $(M L=75 \mathrm{~cm})$

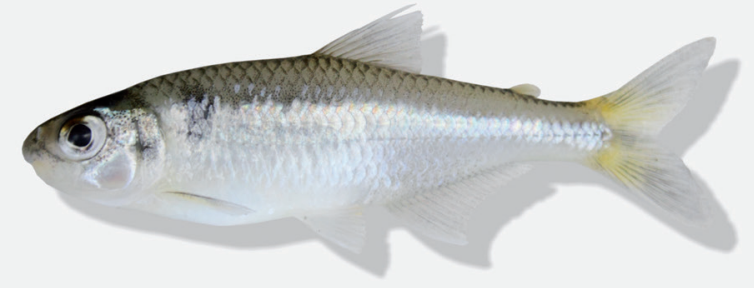

Piabina argentea $(M L=7.3 \mathrm{~cm})$

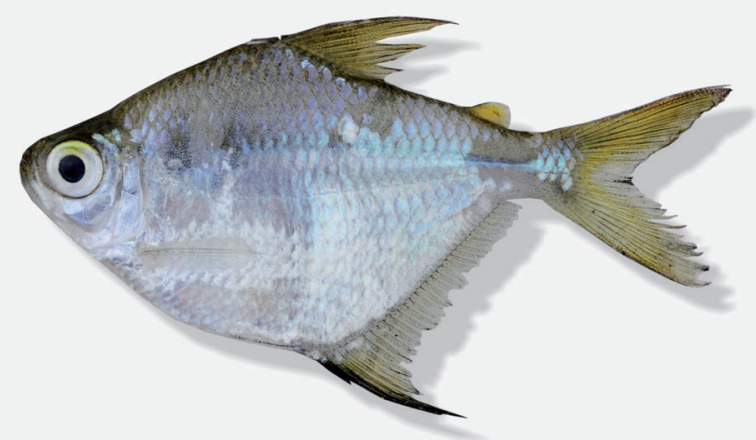

Orthospinus franciscensis $(M L=7.4 \mathrm{~cm})$

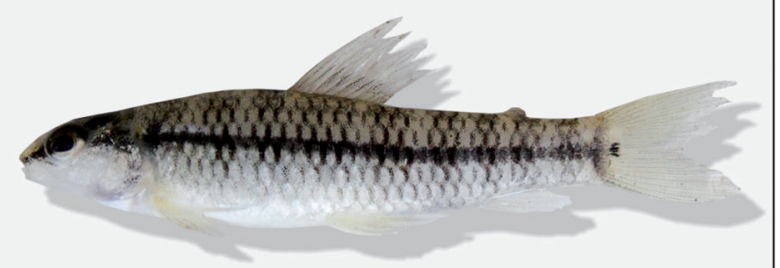

Characidium zebra $(M L=7.4 \mathrm{~cm})$

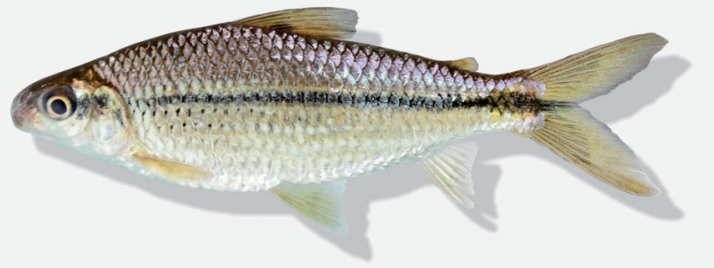

Steindachnerina elegans $(M L=10.6 \mathrm{~cm})$

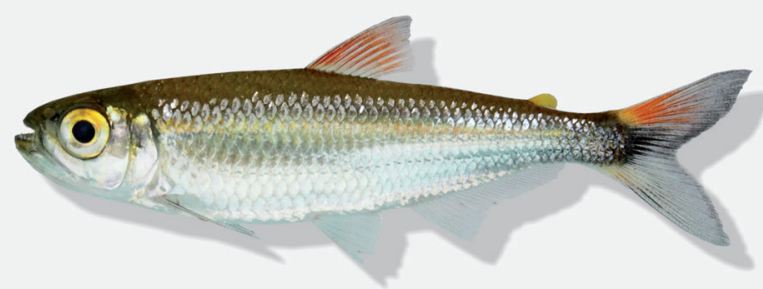

Bryconops sp. $\left(M L=6.5 \mathrm{~cm}^{*}\right)$

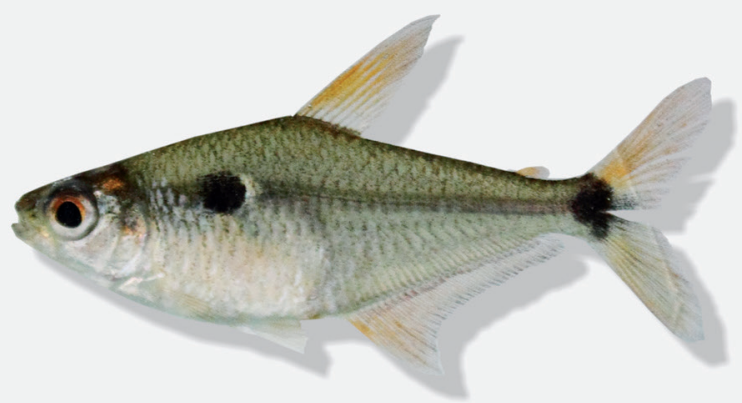

Phenacogaster franciscoensis $(M L=4.2 \mathrm{~cm})$

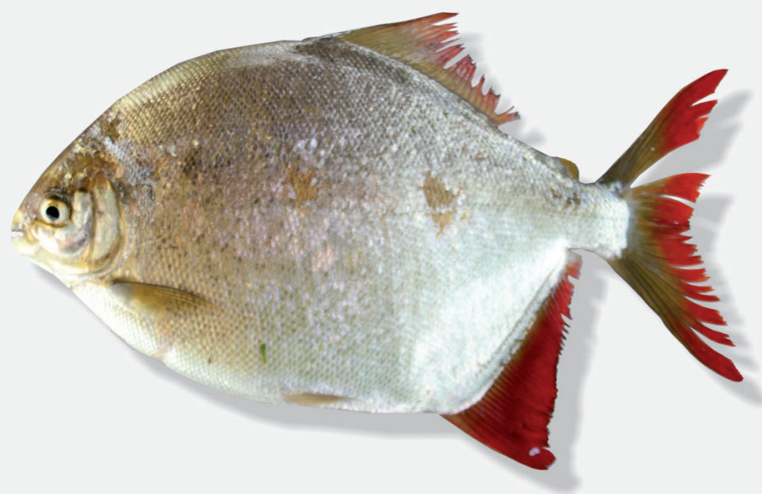

Myleus micans $(M L=27 \mathrm{~cm})$

Figure 4. Representative species belonging to the Characiformes, Siluriformes, Gymnotiformes, Cichliformes and Synbranchiformes orders from the Rio Carinhanha basin. ML = Maximum length recorded by Froese \& Pauly (2020). * Maximum length of Bryconops sp. was obtained by measuring specimens collected in the Rio Carinhanha basin. Photos: Gilberto N. Salvador and Ruanny Casarim. 


\section{Siluriformes}

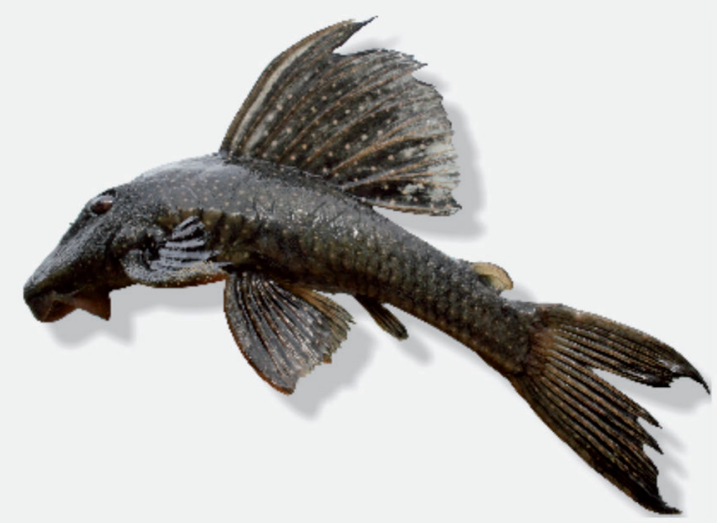

Hypostomus margaritifer $(M L=33 \mathrm{~cm})$

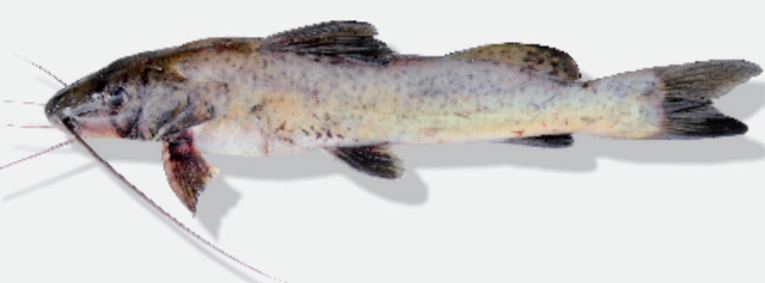

Bagropsis reinhardti $(M L=22 \mathrm{~cm})$

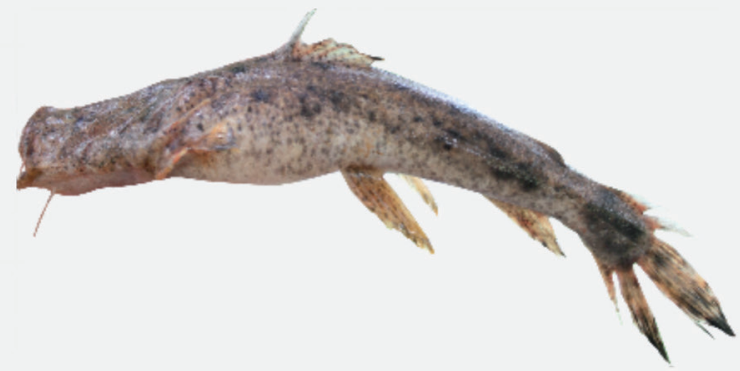

Lophiosilurus alexandri $(M L=72 \mathrm{~cm})$

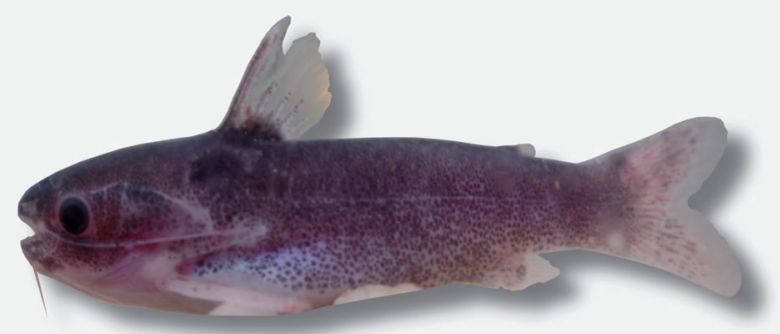

Centromochlus bockmanni $(M L=4.8 \mathrm{~cm})$

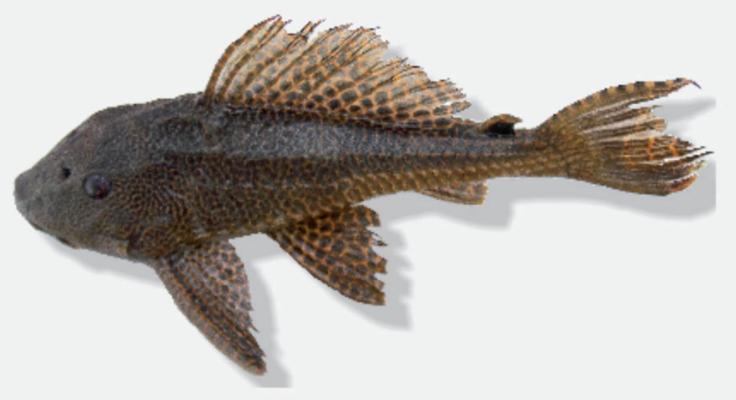

Pterygoplichthys etentaculatus $(M L=30 \mathrm{~cm})$
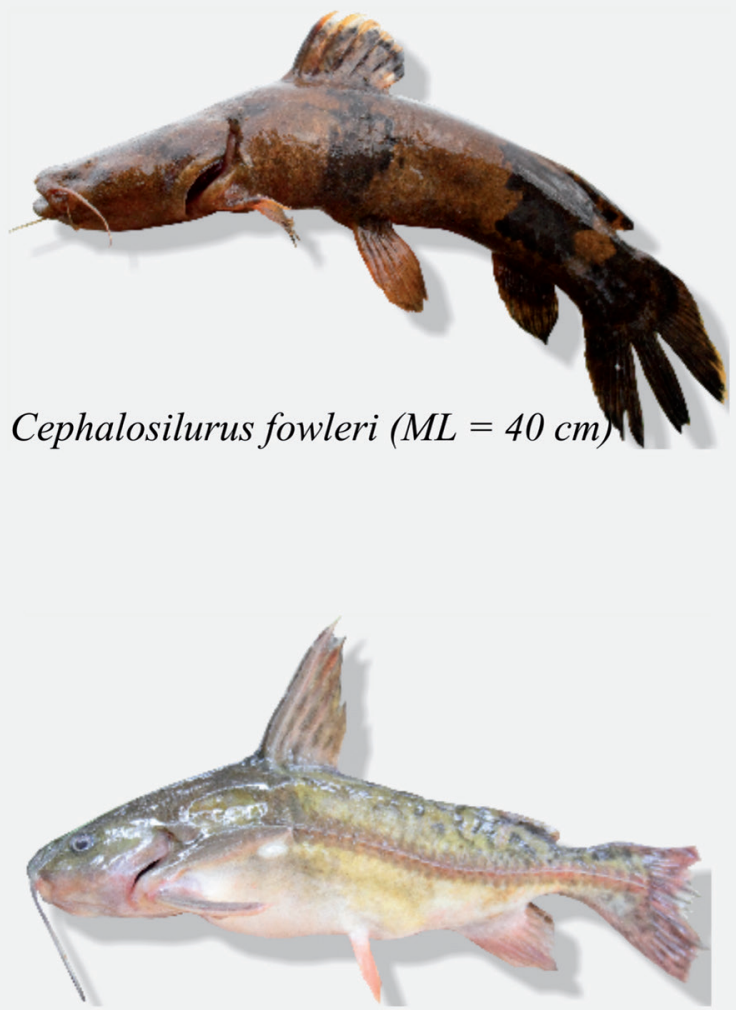

Franciscodoras marmoratus $(M L=36 \mathrm{~cm})$

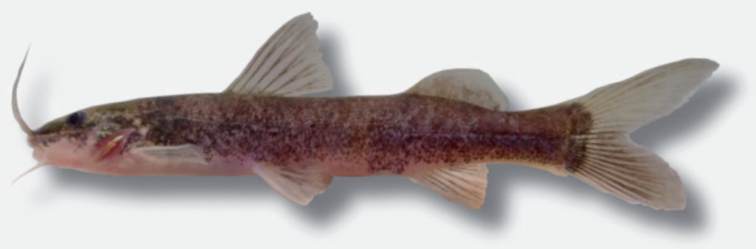

Phenacorhamdia tenebrosa $(M L=7.5 \mathrm{~cm})$

Figure 4. Continued. 


\section{Gymnotiformes}

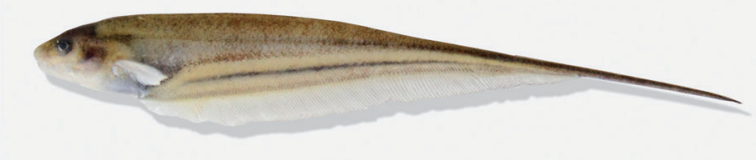

Eigenmannia besouro $(M L=14.8 \mathrm{~cm})$

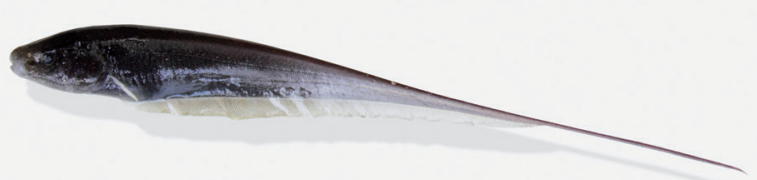

Sternopygus macrurus $(M L=141 \mathrm{~cm})$

Gymnotus gr. carapo $(M L=76 \mathrm{~cm})$

\section{Perciformes}

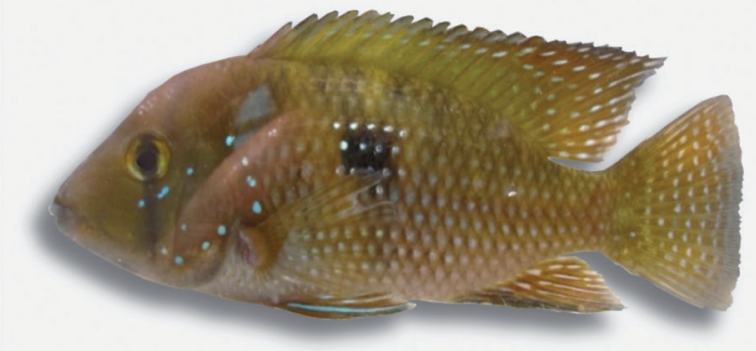

Geophagus brasiliensis $(M L=28 \mathrm{~cm})$

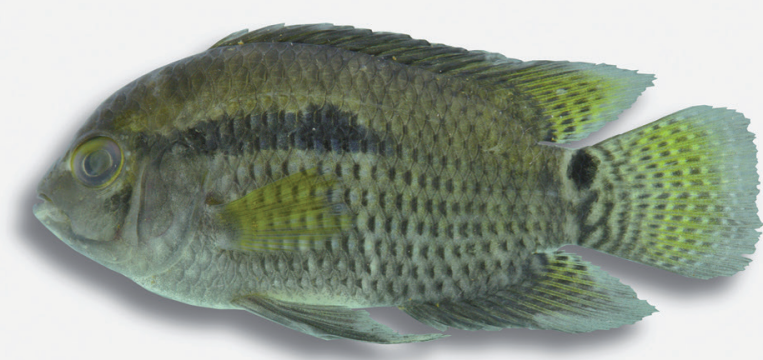

Cichlasoma sanctifranciscense $(M L=8.8 \mathrm{~cm})$

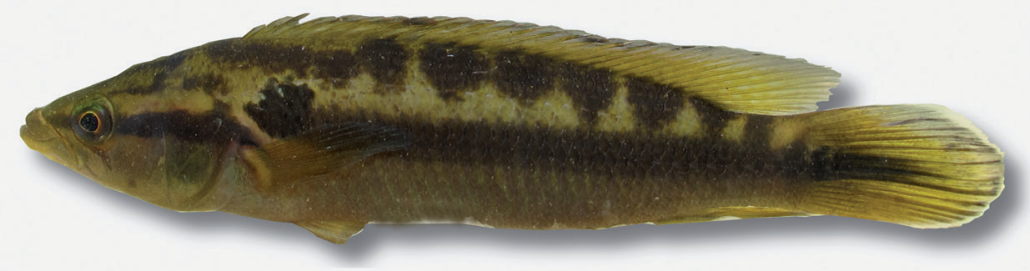

Crenicichla lepidota $(M L=20.9 \mathrm{~cm})$

\section{Synbranchiformes}

Synbranchus sp. $(M L=150 \mathrm{~cm})$ 
2002). The undescribed Characidium has, so far, only been recorded for the Lagoa Bonita, a water body that is connected with the surrounding veredas only during the peak of the rain season. Therefore, preservation of the area in which the species has been recorded, and the identification of new potential sites where it may occur, are necessary for description and conservation of this undescribed species.

Despite recording a similar number (five species) of non-native species to the average observed in other tributaries of the Rio São Francisco (Alves \& Leal, 2010), their occurrence in the Rio Carinhanha was restricted to the lower section of the basin. The introduction of

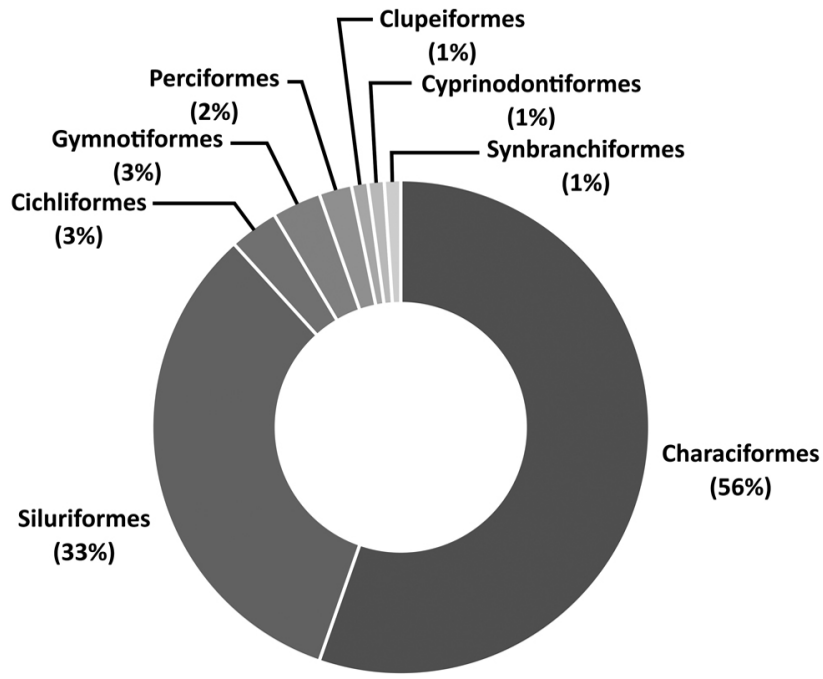

Figure 5. Distribution of ichthyofauna richness by order in the Rio Carinhanha basin.

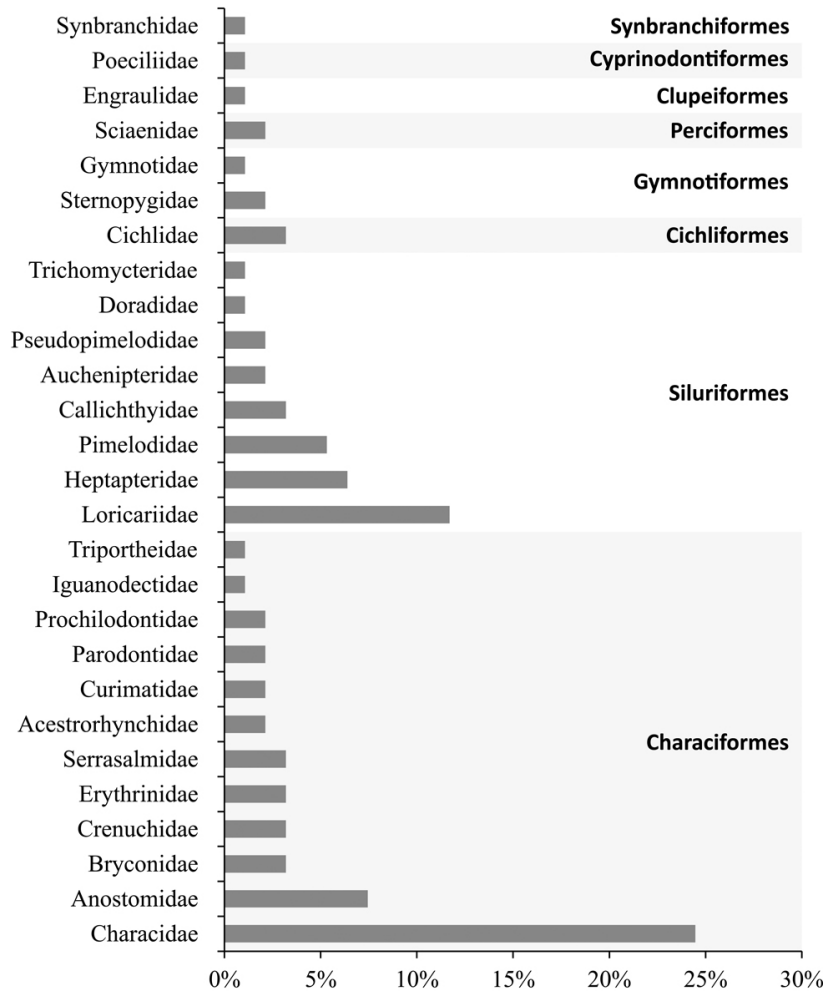

Figure 6. Distribution of ichthyofauna richness by family in the Rio Carinhanha basin. these species have occurred at different points in the São Francisco basin (Alves \& Leal, 2010; Pompeu \& Godinho, 2003; Salvador-Jr. \& Silva, 2011). The area where this group of species was recorded coincides with the most anthropogenic disturbed section of the basin (Borges \& Santos, 2009), which increases the probability of introduction. However, natural dispersal, which is a further step in establishing viable populations in the invaded environment (Blackburn et al., 2011), may also be the source of non-native species in the basin.

Of the great migratory fish species of the Rio São Francisco, only Conorhynchos conirostris was not registered in this study, and there are no recent records of such species for the section close to the Rio Carinhanha (Alves \& Bockmann, 2008). Prochilodus spp. were found in practically the entire length of the Rio Carinhanha, indicating the absence of natural barriers. These species, which represent a large part of the fish biomass of the Rio São Francisco (Sato \& Godinho, 2003), were recorded from the Grande Sertão Veredas Park area to the region near the mouth. However, records of $P$. corruscans, $B$. orthotaenia, and $S$. franciscanus were restricted to the lower section of the basin.

The Rio Carinhanha basin is home to $27 \%$ of the threatened fish species of the Rio São Francisco (Vieira

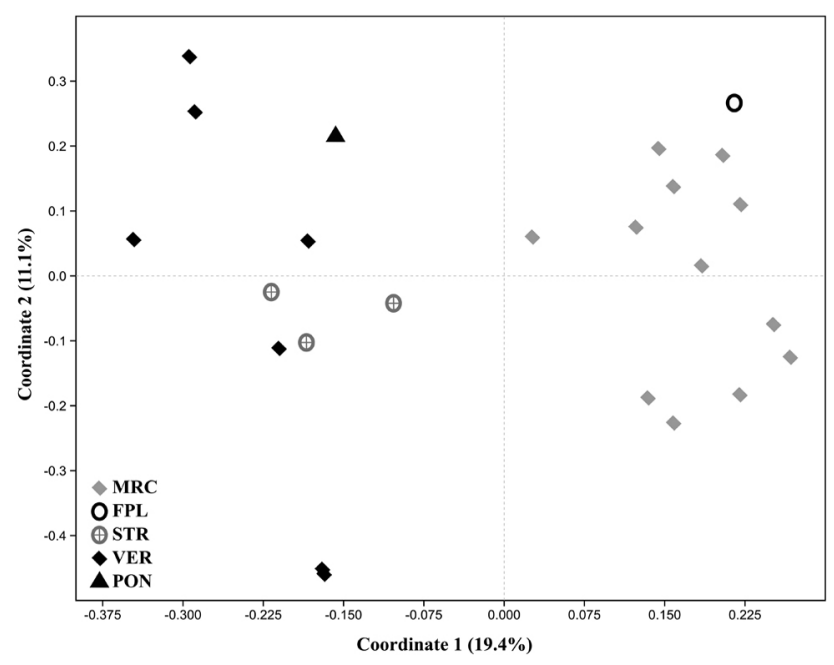

Figure 7. Ordination using $\mathrm{PCOA}$ based on Jaccard distance of the habitat groups showing the difference between main river channel and floodplain lagoons (MRC+FPL) and veredas, streams, and permanent ponds (VER+STR+PON) in coordinate 1.

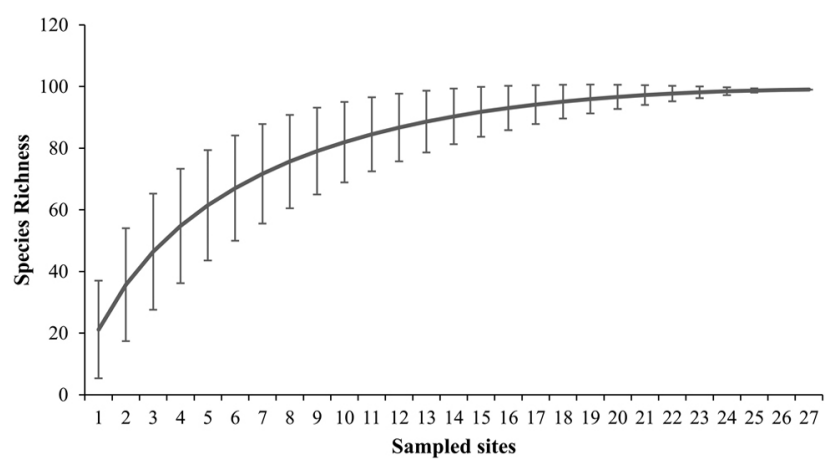

Figure 8. Rarefaction of the observed richness by sample. 
et al., 2008; MMA, 2014; IUCN, 2015) (excluding rivulid fishes), a value close to that observed for the Rio Pandeiros and Rio Paraopeba basins, but lower than that observed for the Rio das Velhas (Alves \& Leal, 2010). The catfish $B$. reinhardti was the only threatened species recorded in the most conserved section of the basin (Borges \& Santos, 2009). The preference for larger environments may be the main reason for the absence of other endangered species in the upper section. Spatial segregation between the two Brycon species is commonly observed in the Rio São Francisco basin, with $B$. orthotaenia tending to occupy the lower sections of the tributaries and the main river channel (Lima, 2017). On the other hand, L. alexandri inhabits more lentic environments (Santos et al., 2013), which are more common in lower sections.

The observed similarity between the main river channel and floodplain lagoons can be explained by the connectivity between these two environments during the flood pulses. Moreover, a similarity between streams and veredas is expected, since veredas are generally associated with smaller water bodies (Boaventura, 1981). The veredas have an important ecological significance, but they have been heavily impacted by human action (Drummond et al., 2005). Their conservation in the Carinhanha basin can allow the protection of an important portion of the basin's fish species, since there is a high intraspecific variation in the ichthyofauna in this habitat. The segregation of the ichthyofauna from Lagoa Bonita, a permanent pond, is due to its low richness and the recording of an undescribed species (Characidium sp.), which is so far only known for this habitat.

The fish species richness recorded during the present study represents $97 \%$ of the estimated richness for the Carinhanha basin by Jackknife methodology, reflecting the stabilization of the species accumulation curve. This reflects the sampling effort in different habitats, like the main river channel, floodplain lagoons, and streams. However, we expect an increase in the number of species with additional collections in the basin, especially in poorly sampled habitats, like floodplain lagoons and streams. The absence of collections in streams located in the lower section of the basin should also be highlighted, where there is a predominance of tropical dry forest. In this region, located in the north of the Minas Gerais state, many streams are intermittent (Paiva, 1982) and there was no flow during the period when the surceys were done.

This study provides evidence for the importance of inventorying the still poorly explored tributaries in the upper-middle section of the Rio São Francisco. In addition to presenting a rich fish fauna, this region may harbor species new to science, as was observed in this study. Because there are important lotic remnants, this area still contains important populations of migratory fish, as well as species threatened with extinction. Knowledge of the ichthyofauna in a key for more sound discussions about the conservation of fishes in the Rio Carinhanha basin, expanding alternatives to maintain fish biodiversity in the upper-middle section of the Rio São Francisco.

\section{AUTHOR CONTRIBUTIONS}

Gilberto Nepomuceno Salvador conceived and designed the experiments, performed the experiments, analyzed the data, prepared figures and/or tables, authored or reviewed drafts of the paper, and approved the final draft. Gustavo Ribeiro Rosa analyzed the data, authored or reviewed drafts of the paper, and approved the final draft. Ruanny Casarim conceived and designed the experiments, performed the experiments, analyzed the data, prepared figures and/or tables, authored or reviewed drafts of the paper, and approved the final draft. Yuri Malta Caldeira conceived and designed the experiments, performed the experiments, analyzed the data, prepared figures and/or tables, authored or reviewed drafts of the paper, and approved the final draft. Paulo Santos Pompeu conceived and designed the experiments, analyzed the data, authored or reviewed drafts of the paper, and approved the final draft.

\section{ACKNOWLEDGEMENTS}

We would like to thank Catumbi Energia, the Fundação Grupo Boticário de Proteção à Natureza, and Coordenação de Aperfeiçoamento de Pessoal de Nível Superior (CAPES) for financial support. We would also like to thank our colleagues Luiz Sergio Ferreira Martins and Laura V. França, managers of the Grande Sertão Veredas National Park at the time when the present study was conducted. Daniel Tregidgo and Jessica Schulte for reviewing the English, and lago Penido for his helpful input. We also thank the residents of many places (Porto Cajueiro, Lodo, Cachoeira do Gibão, Pitarana) who welcomed us, let us set up camp in the backyard of their houses, and told us stories of the fish and the river. We would also like to thank the fisherman Edivaldo Estevam, a natural companion in fieldwork and a teacher of the art of fishing. PSP received research fellowships from CNPq (CNPq № 303548/2017-7) and FAPEMIG (№ PPM-00608/15).

\section{REFERENCES}

Alves, C.B.M. \& Bockmann, F.A. 2008. Conorhynchos conirostris. In: Rosa, R.S. \& Lima, F.C.T. Livro vermelho da fauna brasileira ameaçada de extinção: Peixes. Brasília, Ministérios do Meio Ambiente. v. 6, p. 226-228.

Alves, C.B.M. \& Leal, C.G. 2010. Aspectos da conservação da fauna de peixes da bacia do rio São Francisco em Minas Gerais. MG Biota, 2: 26-44.

Alves, C.B.M. \& Pompeu, P.S. 2010. A fauna de peixes da bacia do rio das Velhas no final do século XX. In: Alves, C.B.M. \& Pompeu, P.S. Peixes do rio das Velhas: passado e presente. Belo Horizonte, Argvmentvm, 167-169.

Alves, C.B.M.; Vieira, F. \& Pompeu, P.S. 2009. Ictiofauna da Bacia Hidrográfica do Rio São Francisco. In: Vizentin, R.R. Programa Zoneamento EcológicoEconômico: Caderno Temático - Biodiversidade. Brasília, Ministério do Meio Ambiente/SEDR/SBF. p. 110-130.

Alves, C.B.M.; Vieira, F. \& Pompeu, P.S. 2011. Ictiofauna da bacia hidrográfica do rio São Francisco. In: Ministério do Meio Ambiente Diagnóstico do macrozoneamento ecológico-econômico da bacia hidrográfica do rio São Francisco. Brasília, Ministério do Meio Ambiente. p. 226-241. 
Barbosa, J.M.; Soares, E.C.; Cintra, I.H.A.; Hermann, M. \& Araújo, A.R.R. 2017. Perfil da ictiofauna da bacia do rio São Francisco. Acta of Fisheries and Aquatic Resources, 5(1): 70-90.

Belei, F.; Santana Sampaio, W.M.; Giongo, P. \& Dergam, J. 2016. Ictiofauna de área prioritária para conservação, Médio São Francisco, Minas Gerais, sudeste do Brasil. Neotropical Biology \& Conservation, 11(2): 94-100.

Blackburn, T.M.; Pyšek, P.; Bacher, S.; Carlton, J.T.; Duncan, R.P.; Jarošík, V.; Wilson, J.R.U. \& Richardson, D.M. 2011. A proposed unified framework for biological invasions. Trends in Ecology \& Evolution, 26(7): 333-339.

Boaventura, R.S. 1981. Contribuição aos estudos sobre a evolução das veredas. In: Fundação Centro Tecnológico de Minas Gerais (Orgs.). Segundo plano de desenvolvimento integrado no Noroeste Mineiro - Informe Técnico. Belo Horizonte, CETEC. v. 3, p. 13-17.

Borges, K.M.R. 2009. Avaliação da susceptibilidade erosiva da bacia do rio Carinhanha (MG/BA) por meio de EUPS - Equação Universal de Perda de Solos. (Masters Dissertation). Brasília, Universidade de Brasília.

Borges, K.M.R. \& Santos, P.M.C. 2009. Modelo Linear de Mistura Espectral MLME aplicado ao monitoramento do Cerrado, Bacia do Rio Carinhanha (MG-BA). In: Epiphanio, J.C.N. \& Galvão, L.S. (Eds.). Simpósio Brasileiro de Sensoriamento Remoto, 14 $^{\circ}$. Anais. São José dos Campos, Instituto Nacional de Pesquisa Espacial. p. 5663-5669.

Britski, H.A.; Sato, Y. \& Rosa, A.B.S. 1988. Manual de identificação de peixes da região de Três Marias. Brasília, CODEVASF.

Casatti, L. \& Castro, R.M.C. 1998. A fish community of the São Francisco River headwaters riffles, southeastern Brazil. Ichthyological Exploration of Freshwaters, 9(3): 229-242.

Costa, W.J.E.M. 2002. Peixes anuais brasileiros: diversidade e conservação. Curitiba, Editora UFPR.

Domingos, F.F.T.; Thomé, R.G.; Ribeiro, R.I.M.A.; Souza, H.A.V. \& Santos, H.B. 2013. Assessment of fish assemblage in an urban system, Itapecerica River, upper São Francisco River basin, Divinópolis, Minas Gerais, Brazil. Check List, 9(3): 482-486.

Drummond, G.M.; Martins, C.S.; Machado, A.B.M.; Sebaio, F.A. \& Antonini, Y. 2005. Biodiversidade em Minas Gerais: um atlas para sua conservação. Belo Horizonte, Fundação Biodiversitas.

Dudley, N. 2008. Guidelines for applying protected area management categories. Switzerland, International Union for Conservation of Nature. 143p. (Best Practice Protected Area Guidelines Serie, n. 21) Disponível em: https://portals.iucn.org/library/sites/library/files/documents/PAG021.pdf.

Empresa Brasileira de Pesquisa Agropecuária (EMBRAPA). 2012. 0 cerrado. Available at: http://www.cpac.embrapa.br/unidade/ocerrado. Access in: 10/01/2018

Fricke, R.; Eschmeyer, W.N. \& Van der Laan, R. 2020. Catalog of fishes: genera, species, references. Available at: http://researcharchive.calacademy.org/ research/ichthyology/catalog/fishcatmain.asp. Access in: 03/03/2020.

Froese, R. \& Pauly, D. 2020. FishBase. Available at: http://www.fishbase.org. Access in: 10/09/2019.

Gaspar, M.T.P.; Campos, J.E.G. \& Cadamuro, A.L.M. 2007. Condições de infiltração em solos na região de recarga do sistema aqüífero Urucuia no oeste da Bahia sob diferentes condições de usos. Revista Brasileira de Geociências, 37: 542-550.

Godinho, A.L. \& Godinho, H.P. 2003. Breve visão do São Francisco. In: Godinho, H.P. \& Godinho, A.L. (Eds.). Águas, peixes e pescadores do São Francisco das Minas Gerais. Belo Horizonte, Editora PUC Minas. p. 15-24.

Instituto Brasileiro de Geografia e Estatística (IBGE). 2007. Inventário da biodiversidade do bioma Cerrado: peixes do Parque Nacional Grande Sertão Veredas - MG/GO. Rio de Janeiro, Instituto Brasileiro de Geografia e Estatística.
International Union for Conservation of Nature and Natural Resources (IUCN). 2015. The IUCN Red List of Threatened Species. Available at: http://www. iucnredlist.org. Access in: 02/09/2015.

Karr, J.R. \& Schlosser, I.J. 1978. Water resources and the land-water interface. Science, New York, 201: 229-34.

Lima, C.F.T. 2017. A revision of the cis-andean species of the genus Brycon Müller \& Troschel (Characiformes: Characidae). Zootaxa, 4222(1): 1-189.

Lowe-McConnell, R.H. 1987. Ecological studies in tropical fishes communities. Cambridge, Cambridge University Press.

Luz, S.C.; Lima, H.C. \& Severi, W. 2012. Composição da ictiofauna em ambientes marginais e tributários do médio-submédio rio São Francisco. Revista Brasileira de Ciências Agrárias, 7(2): 358-366.

Mendes, L.A.; de Barros, M.T.L.; Zambon, R.C. \& Yeh, W.W-G. 2015. Trade-Off analysis among multiple water uses in a hydropower system: case of São Francisco River Basin, Brazil. Journal of Water Resources Planning and Management, 141(10): 04015014-1-04015014-10

Menezes, N.A.; Weitzman, S.H. \& Teixeira, T.F. 2016. Redescription of Hysteronotus megalostomus (Characiformes: Characidae: Stevardiinae), a poorly known characid from tributaries of the Rio São Fancisco, Brazil with comments on the conservation of the species. Journal of Fish Biology, 89(1): 495-509.

Ministério do Meio Ambiente (MMA). 2014. Portaria MMA № 445: lista nacional das espécies de invertebrados aquáticos e peixes ameaçados de extinção. Brasília, Ministério do Meio Ambiente. Disponível em: https:// www.icmbio.gov.br/portal/images/stories/docs-plano-de-acaoARQUIV0/00-saiba-mais/05 - PORTARIA MMA N\%C2\%BA 445 DE 17 DE DEZ DE 2014.pdf.

Ministério do Meio Ambiente (MMA)/Instituto Brasileiro do Meio Ambiente e dos Recursos Naturais Renováveis (IBAMA). 2003. Plano de manejo do Parque Nacional Grande Sertão Veredas. Brasília, Ministério do Meio Ambiente/Instituto Brasileiro do Meio Ambiente e dos Recursos Naturais.

Moraes, M.B.R. 2011. Implementação das Áreas de Proteção Ambiental Federais no Brasil: 0 enfoque da gestão. (Doctoral Thesis), Universidade de São Paulo, São Paulo.

Oksanen, J.; Blanchet, F.G.; Friendly, M.; Kindt, R.; Legendre, P.; McGlinn, D.; Minchin, P.R.; O'Hara, R.B.; Simpson, G.L.; Solymos, P.; Henry; M.; Stevens, H.; Szoecs, E. \& Wagner, H. 2013. Package 'vegan'. Community ecology package, 2(9): 1-295.

Paiva, M.P. 1982. Grandes represas do Brasil. Brasília, Editerra.

Pereira, S.B.; Pruski, F.F.; Silva, D.D. \& Ramos, M.M. 2007. Estudo do comportamento hidrológico do Rio São Francisco e seus principais afluentes. Revista Brasileira de Engenharia Agrícola e Ambiental, 22: 615-622.

Pompeu, P.S. \& Godinho, H.P. 2003. Ictiofauna de três lagoas marginais do médio São Francisco. In: Godinho, H.P. \& Godinho, A.L. Águas, peixes e pescadores do São Francisco das Minas Gerais. Belo Horizonte, Editora PUC Minas. p. 167-181.

Prado, I.G. \& Pompeu, P.S. 2014. Vertical and seasonal distribution of fish in Três Marias reservoir. Lake and Reservoir Management, 30(4): 393-404.

R Core Team. 2015. R: A Language and Environment for Statistical Computing. Available at: https://www.R-project.org. Access in: 15/03/2018.

Reis, R.E.; Albert, J.S.; Di Dario, F.; Mincarone, M.M.; Petry, P. \& Rocha, L.A. 2016. Fish biodiversity and conservation in South America. Journal of Fish Biology, 89: 12-47.

Rosa, R.; Gomes Filho, G.; Menezes, N.A.; Shibatta, O.A. \& Costa, W.J.E.M. 2003. Biota aquática: áreas e ações prioritárias para a conservação da Caatinga. In: da Silva, J.M.C.; Tabarelli, M. \& Lins, M.T.F.L.V. (Orgs.). Biodiversidade da Caatinga: áreas e ações prioritárias para a conservação. Brasília, Ministério do Meio Ambiente/Secretaria de Biodiversidade e Florestas. 
Salvador-Jr., L.F.\& Silva, F.A. 2011. Actinopterygii, Siluriformes, Callichthyidae, Hoplosternum littorale (Hancock, 1828): Distribution extension in the upper São Francisco River region, southeast Brazil. Check List, 7: 621-625.

Sanches, B.0.; Becker, B.; Gomes, P.L.A. \& Santos, G.B. 2014. A ictiofauna de quatro reservatórios da CEMIG: caracterização das comunidades. In: Callisto, M.; Alves, C.B.M.; Lopes, J.M. \& Castro, M.A. Condições ecológicas em bacias hidrográficas de empreendimentos hidrelétricos. Belo Horizonte, Companhia Energética de Minas Gerais, p. 185-214.

Santos, H.B.; Sampaio, E.V.; Arantes, F.P. \& Sato, Y. 2013. Induced spawning and reproductive variables of the catfish Lophiosilurus alexandri steindachner, 1876 (Siluriformes: Pseudopimelodidae). Neotropical Ichthyology, 11(3): 607-614.

Sato, Y. \& Godinho, H.P. 2003. Migratory fishes of the São Francisco river. In: Carolsfeld, J.; Harvey, B.; Ross, C. \& Baer, A. (Eds.). Migratory fishes of South America: biology, fisheries and conservation status. Victoria, Canada, World Fisheries Trust, p. 195-232.

Sato, Y.; Cardoso, E.L. \& Amorim, J.C. 1987. Peixes das lagoas marginais do rio São Francisco a montante da represa de Três Marias (Minas Gerais). Brasília, Codevasf.

Silva, A.R.M.; Santos, G.B. \& Ratton, T. 2006. Fish community structure of Juramento reservoir, São Francisco River basin, Minas Gerais, Brazil. Revista Brasileira de Zoologia, 23(3): 832-840.

Silva, J.M.C. \& Bates, J.M. 2002. Biogeographic patterns and conservation in the South American Cerrado: a tropical savanna hotspot: the Cerrado, which includes both forest and savanna habitats, is the second largest
South American biome, and among the most threatened on the continent. BioScience, 52(3): 225-234.

Silva, J.M.C.; Leal, I.R. \& Tabarelli, M. 2018. Caatinga: the largest tropical dry forest region in South America. Switzerland, Springer.

Tavares-Júnior, C.; Eskinazi-Sant'Anna, E.M. \& Pires, M.R.S. 2020. Environmental drivers of tadpole community structure in temporary and permanent ponds. Limnologica, Berlin, 81: 125764.

Van der Laan, R \& Fricke, R. 2020. Eschmeyer's catalog of fishes: family-group names. Available at: http://www.calacademy.org/scientists/catalog-offishes-family-group-names. Access in: 03/03/2020.

Vannote, R.L.; Minshall, G.W.; Cummins, K.W.; Sedell, J.R. \& Cushing, C.E. 1980. The river continuum concept. Canadian Journal of Fisheries and Aquatic Sciences, 37: 130-137.

Vieira, F.; Alves, C.B.M.; Pompeu, P.S. \& Vono, V. 2008. Peixes ameaçados de Minas Gerais. In: Drummond, G.M.; Machado, A.B.M.; Martins, C.S.; Mendonça, M.P. \& Stehmann, J.R. Listas vermelhas das espécies da fauna e flora ameaçadas de extinção em Minas Gerais. Belo Horizonte, Fundação Biodiversitas. p. 8-28.

Vieira, F.; Santos, G.B. \& Alves, C.B.M. 2005. A ictiofauna do Parque Nacional da Serra do Cipó (Minas Gerais, Brasil) e áreas adjacentes. Lundiana, 6(suppl.): 77-85.

Viglio, E.P.; Cunha, J.R. \& Silva, A.A. 2011. Geoquímica multiusos no estado de Minas Gerais: as bacias dos rios Urucuia e Carinhanha. In: Mexias, A.S.; Formoso, M.L.L.; Mizusaki, A.M.P. et al. (Eds.). Congresso Brasileiro de Geoquímica, $13^{\circ}$ Simpósio de Geoquímica dos Países do Mercosul, $3^{\circ}$. Anais. Gramado, Gramado, UFRS. p. 5-408.

\section{SUPPLEMENTARY MATERIALS}

\section{Supplementary Materials 1}

Sampled sites along the Rio Carinhanha basin grouped by habitat. For each site, the table shows its geographic coordinates, altitude, and Strahler order.

\begin{tabular}{|c|c|c|c|c|}
\hline Group & Latitude & Longitude & Alt. (m) & Order \\
\hline \multirow[t]{12}{*}{ Main river channel (MRC) } & $15^{\circ} 01^{\prime} 35^{\prime \prime S}$ & $45^{\circ} 38^{\prime} 38^{\prime \prime} \mathrm{W}$ & 695 & 5 \\
\hline & $14^{\circ} 46^{\prime} 23^{\prime \prime S}$ & $45^{\circ} 13^{\prime} 53^{\prime \prime} W$ & 675 & 5 \\
\hline & $14^{\circ} 41^{\prime} 41^{\prime \prime} \mathrm{S}$ & $45^{\circ} 2^{\prime} 44^{\prime \prime} \mathrm{W}$ & 628 & 5 \\
\hline & $14^{\circ} 39^{\prime} 57^{\prime \prime S}$ & $44^{\circ} 59^{\prime} 51^{\prime \prime} \mathrm{W}$ & 619 & 5 \\
\hline & $14^{\circ} 32^{\prime} 34^{\prime \prime S}$ & $44^{\circ} 50^{\prime} 44^{\prime \prime} \mathrm{W}$ & 569 & 5 \\
\hline & $14^{\circ} 19^{\prime} 40^{\prime \prime} \mathrm{S}$ & $44^{\circ} 30^{\prime} 59^{\prime \prime} \mathrm{W}$ & 489 & 5 \\
\hline & $14^{\circ} 17^{\prime} 06^{\prime \prime S}$ & $44^{\circ} 4^{\prime} 18^{\prime \prime} W$ & 451 & 6 \\
\hline & $14^{\circ} 17^{\prime} 19^{\prime \prime} \mathrm{S}$ & $43^{\circ} 56^{\prime} 55^{\prime \prime} \mathrm{W}$ & 449 & 6 \\
\hline & $14^{\circ} 10^{\prime} 37^{\prime \prime S}$ & $44^{\circ} 45^{\prime} 12^{\prime \prime} \mathrm{W}$ & 539 & 4 \\
\hline & $14^{\circ} 16^{\prime} 40^{\prime \prime} \mathrm{S}$ & $44^{\circ} 28^{\prime} 16^{\prime \prime} \mathrm{W}$ & 496 & 5 \\
\hline & $14^{\circ} 25^{\prime} 05^{\prime \prime S}$ & $44^{\circ} 27^{\prime} 55^{\prime \prime} \mathrm{W}$ & 453 & 5 \\
\hline & $14^{\circ} 16^{\prime} 10^{\prime \prime} \mathrm{S}$ & $44^{\circ} 10^{\prime} 29^{\prime \prime} \mathrm{W}$ & 520 & 5 \\
\hline \multirow[t]{6}{*}{ veredas (VER) } & $14^{\circ} 50^{\prime} 14^{\prime \prime S}$ & $45^{\circ} 16^{\prime} 52^{\prime \prime} \mathrm{W}$ & 684 & 3 \\
\hline & $15^{\circ} 17^{\prime} 49^{\prime \prime} \mathrm{S}$ & $45^{\circ} 54^{\prime} 10^{\prime \prime} \mathrm{W}$ & 753 & 2 \\
\hline & $15^{\circ} 11^{\prime} 24^{\prime \prime S}$ & $45^{\circ} 53^{\prime} 13^{\prime \prime} \mathrm{W}$ & 725 & 2 \\
\hline & $15^{\circ} 10^{\prime} 33^{\prime \prime} \mathrm{S}$ & $45^{\circ} 41^{\prime} 10^{\prime \prime} \mathrm{W}$ & 745 & 2 \\
\hline & $15^{\circ} 13^{\prime} 50^{\prime \prime} \mathrm{S}$ & $45^{\circ} 38^{\prime} 56^{\prime \prime} W$ & 750 & 3 \\
\hline & $15^{\circ} 07^{\prime} 01^{\prime \prime} \mathrm{S}$ & $45^{\circ} 28^{\prime} 12^{\prime \prime} \mathrm{W}$ & 726 & 4 \\
\hline \multirow[t]{3}{*}{ Streams (STR) } & $15^{\circ} 18^{\prime} 38^{\prime \prime S}$ & $45^{\circ} 57^{\prime} 27^{\prime \prime} \mathrm{W}$ & 760 & 3 \\
\hline & $14^{\circ} 36^{\prime} 08^{\prime \prime} \mathrm{S}$ & $44^{\circ} 51^{\prime} 49^{\prime \prime} \mathrm{W}$ & 605 & 3 \\
\hline & $15^{\circ} 19^{\prime} 03^{\prime \prime S}$ & $45^{\circ} 59^{\prime} 05^{\prime \prime} \mathrm{W}$ & 787 & 3 \\
\hline \multirow[t]{2}{*}{ Floodplain lagoons (FPL) } & $14^{\circ} 17^{\prime} 03^{\prime \prime S}$ & $43^{\circ} 57^{\prime} 12^{\prime \prime} \mathrm{W}$ & 450 & \\
\hline & $14^{\circ} 19^{\prime} 13^{\prime \prime S}$ & $43^{\circ} 47^{\prime} 30^{\prime \prime} \mathrm{W}$ & 439 & \\
\hline \multirow[t]{2}{*}{ Permanent ponds (PON) } & $14^{\circ} 48^{\prime} 31^{\prime \prime S}$ & $44^{\circ} 56^{\prime} 52^{\prime \prime} \mathrm{W}$ & 691 & \\
\hline & $15^{\circ} 02^{\prime} 01^{\prime \prime S}$ & $45^{\circ} 34^{\prime} 10^{\prime \prime} \mathrm{W}$ & 706 & \\
\hline
\end{tabular}




\section{Supplementary Materials 2}

Species vouchers of fishes caught in the Rio Carinhanha basin. Acronyms: MCNIP (Museu de Ciências Naturais da PUC Minas); CI-UFLA (Universidade Federal de Lavras); ZUEC (Museu de Zoologia da Universidade de Campinas); ANSP (The Academy of Natural Sciences of Drexel University - from Menezes et al., 2016).

\begin{tabular}{|c|c|}
\hline Species & Voucher \\
\hline Acestrorhynchus britskii & MCNIP 1576 \\
\hline Acestrorhynchus lacustris & MCNIP 1736 \\
\hline Anchoviella vaillanti & MCNIP 1575 \\
\hline Apareiodon hasemani & MCNIP 1764/1766 \\
\hline Apareiodon sp.A & MCNIP 1765 \\
\hline Astyanax cf. bockmanni & CI-UFLA 0929 \\
\hline Astyanax fasciatus & CI-UFLA 0930 \\
\hline Astyanax lacustris & CI-UFLA 0931 \\
\hline Astyanax rivularis & CI-UFLA 0932 \\
\hline Bagropsis reinhardti & MCNIP 1561 \\
\hline Bryconops sp. & MCNIP 1745 \\
\hline Brycon orthotaenia & ZUEC 9189 \\
\hline Centromochlus bockmanni & CI-UFLA 0935 \\
\hline Cephalosilurus fowleri & MCNIP 1734 \\
\hline Cetopsorhamdia iheringi & CI-UFLA 0936 \\
\hline Characidium sp. & MCNIP 1629 \\
\hline Characidium cf. zebra & CI-UFLA 0937/MCNIP 1579 \\
\hline Characidium fasciatum & CI-UFLA 0938 \\
\hline Cichlasoma sanctifranciscense & MCNIP 1573/CI-UFLA 0939 \\
\hline Compsura heterura & MCNIP 1772 \\
\hline Coptodon rendalli & MCNIP 1767 \\
\hline Corydoras garbei & CI-UFLA 0940 \\
\hline Corydoras lymnades & MCNIP 1567 \\
\hline Corydoras multimaculatus & MCNIP 1568 \\
\hline Crenicichla lepidota & MCNIP 1572/1578 \\
\hline Curimatella lepidura & MCNIP \\
\hline Eigenmannia besouro & CI-UFLA 0941 \\
\hline Franciscodoras marmoratus & MCNIP 1753 \\
\hline Geophagus brasiliensis & CI-UFLA 0942 \\
\hline Gymnotus gr. carapo & CI-UFLA 0943 \\
\hline Harttia longipinna & MCNIP 1749 \\
\hline Hasemania nana & MCNIP 1769 \\
\hline Hemigrammus cf. gracilis & MCNIP 1746/1768 \\
\hline Hemigrammus marginatus & CI-UFLA 0946 \\
\hline Hisonotus vespuccii & MCNIP \\
\hline Hisonotus sp. & CI-UFLA 0947 \\
\hline Hoplerythrinus unitaeniatus & MCNIP 1750 \\
\hline Hoplias intermedius & MCNIP 1559 \\
\hline Hoplias malabaricus & MCNIP 1739 \\
\hline Hoplosternum littorale & MCNIP 1735 \\
\hline Hyphessobrycon micropterus & MCNIP 1741 \\
\hline Hypostomus margaritifer & MCNIP 1562 \\
\hline Hypostomus cf. lima & MCNIP 1773 \\
\hline Hypostomus francisci & MCNIP 1569 \\
\hline Hypostomus velhochico & MCNIP 1570 \\
\hline Hysteronotus megalostomus & ANSP 170504 (Menezes et al., 2016) \\
\hline Imparfinis minutus & CI-UFLA 0949 \\
\hline Lepidocharax burnsi & CI-UFLA 0950/MCNIP 1742 \\
\hline Leporinus marcgravii & MCNIP 1553 \\
\hline Leporinus piau & MCNIP 1551 \\
\hline
\end{tabular}

\begin{tabular}{|c|c|}
\hline Species & Voucher \\
\hline Leporinus taeniatus & MCNIP 1552/1556 \\
\hline Lophiosilurus alexandrii & MCNIP 1737 \\
\hline Megaleporinus obtusidens & MCNIP 1752 \\
\hline Megaleporinus reinhardti & MCNIP 1555 \\
\hline Moenkhausia cf. costae & MCNIP 1748 \\
\hline Moenkhausia sanctaefilomenae & CI-UFLA 0952 \\
\hline Myleus micans & MCNIP 1546/1547 \\
\hline Orthospinus franciscensis & MCNIP 1747 \\
\hline Otocinclus xacriaba & MCNIP 1744 \\
\hline Pachyurus francisci & MCNIP 1738 \\
\hline Pachyurus squamipennis & MCNIP 1560 \\
\hline Pamphorichthys hollandi & MCNIP 1743 \\
\hline Phenacogaster franciscoensis & CI-UFLA 0954 \\
\hline Phenacorhamdia tenebrosa & CI-UFLA 0955 \\
\hline Piabarchus stramineus & MCNIP 1763 \\
\hline Piabina argentea & CI-UFLA 0956 \\
\hline Pimelodella lateristriga & CI-UFLA 0957 \\
\hline Pimelodella laurenti & MCNIP 1770 \\
\hline Pimelodus fur & MCNIP 1771 \\
\hline Pimelodus maculatus & MCNIP 1566 \\
\hline Pimelodus pohli & MCNIP 1733 \\
\hline Prochilodus argenteus & MCNIP 1548 \\
\hline Prochilodus costatus & MCNIP 1549 \\
\hline Pterygoplichthys etentaculatus & MCNIP 1564 \\
\hline Rhamdia aff. quelen & Cl-UFLA 0958 \\
\hline Rineloricaria sp. & CI-UFLA 0959 \\
\hline Roeboides xenodon & MCNIP 1582 \\
\hline Salminus franciscanus & MCNIP 1751 \\
\hline Salminus hilarii & MCNIP 1557 \\
\hline Schizodon knerii & MCNIP 1550/1577 \\
\hline Serrapinus heterodon & CI-UFLA 0960 \\
\hline Serrapinus piaba & CI-UFLA 0961 \\
\hline Serrasalmus brandtii & MCNIP 1580 \\
\hline Steindachnerina elegans & MCNIP 1558 \\
\hline Sternopygus macrurus & MCNIP 1574 \\
\hline Sternopygus macrurus & CI-UFLA 0962 \\
\hline Synbranchus sp. & CI-UFLA 0963 \\
\hline Tetragonopterus chalceus & MCNIP 1740 \\
\hline Trachelyopterus galeatus & MCNIP 1571 \\
\hline Triportheus guentheri & MCNIP 1581 \\
\hline Species & No voucher \\
\hline Astronotus ocellatus & $* * *$ \\
\hline Hyphessobrycon santae & $* * *$ \\
\hline Knodus moenkhausii & $* * *$ \\
\hline Leporellus vittatus & $* * *$ \\
\hline Megalancistrus barrae & $* * *$ \\
\hline Metynnis lippincottianus & $* * *$ \\
\hline Pseudoplatystoma corruscans & $* * *$ \\
\hline Pygocentrus piraya & $* * *$ \\
\hline Cichla piquiti & $* * *$ \\
\hline
\end{tabular}

